\title{
COMMUNICATIONS
}

\section{RETROLENTAL FIBROPLASIA* \\ EARLY DEVELOPMENT AND THE EFFECT OF ACTH IN TREATMENT}

BY

\section{A. BROWN AND BERYL CORNER}

From the Departments of Ophthalmology and Child Health, University of Bristol

RETROLENTAL fibroplasia is a disease developing in both eyes of premature infants after birth, in which an opaque vascularized membrane forms behind the lens. It was first recognized by Terry $(1942 a, b)$ as a separate entity.

\section{Incidence}

The incidence of the disease appears to vary from country to country, and from place to place in the same country (Kinsey and Zacharias, 1949). American writers have quoted the incidence as 7 per cent. (Owens and Owens, 1949a; Gilger, 1949) in infants of $4 \frac{1}{2} \mathrm{lb}$.or less at birth, and as 12 per cent. (Terry, 1945), 15 to 20 per cent. (Owens and Owens, 1949a), and 23 per cent. (Clifford and Weller, 1948) in those of less than $3 \mathrm{lb}$. at birth. From Australia an incidence of 15 per cent. in premature infants in Melbourne is reported by Campbell (1951), and from Paris an incidence of 7.5 per cent. is quoted by Lelong and others (1951). Cross (1950) gives a complete review of the earlier literature.

As indicated above, there is considerable evidence that the incidence of the disease increases as the birth weight decreases. King (1950) followed the original series of Terry (1945), and found that of 238 cases of retrolental fibroplasia, all were under $5 \mathrm{lb}$. at birth, 85 per cent. were under $4 \mathrm{lb}$., and 44 per cent. under $3 \mathrm{lb}$. In Great Britain, Moffatt (1950) found that four out of twelve babies blind from the disease had a birth weight of under $3 \mathrm{lb}$., and the remaining eight had birth weights of 3 to $3 \frac{1}{2} \mathrm{lb}$. In King's series of 238 cases of retrolental fibroplasia there were 52 sets of twins and two sets of triplets. Of these, the disease developed in one twin in eighteen sets and in both twins in eight sets, while one twin in each of the remaining sets died. Apart from its occurrence in twins, where prematurity is probably the causative factor, the disease does not occur in other members of the same family.

Since January, 1946, at Southmead Hospital, Bristol, 434 babies weighing $4 \mathrm{lb} .6 \mathrm{oz}$. or less at birth have survived (i.e., babies in the three lowest weight groups of the Ministry of Health classification of prematurity, 1951). The afterhistory of all these cases has been followed for long enough to be certain that all the advanced irreversible cases of retrolental fibroplasia are known to us. In addition to the four cases successfully treated as described below, there were twelve

* Received for publication January 14, 1952. 
TABLE I

CASES DIAGNOSED AS ADVANCED RETROLENTAL FIBROPLASIA

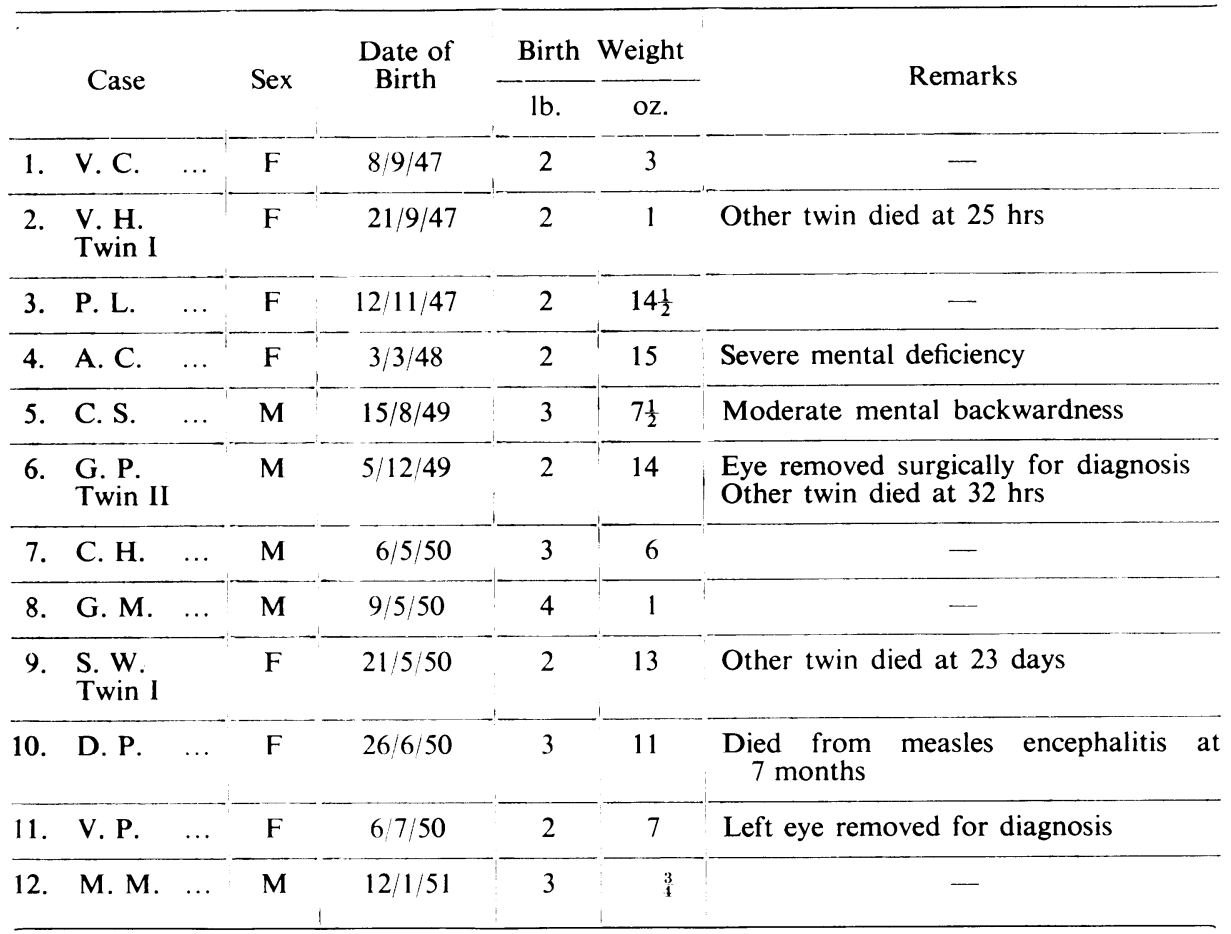

other severely affected children (Table I). This is a total of sixteen cases in nearly 6 years, giving an incidence of 3.7 per cent. for babies in this weight range. It should be noted, however, that during the last 10 months, when all babies of this weight group had been regularly examined ophthalmoscopically, the four successfully treated cases were found among 57 babies, an incidence of 7 per cent. No case is known to have occurred in any heavier premature baby born during this period, although altogether approximately 800 additional babies weighing $5 \mathrm{lb} .8 \mathrm{oz}$. or less at birth survived. It will be noted that nine out of the sixteen cases weighed 3 to $4 \mathrm{lb}$. at birth, and the other seven cases less than $3 \mathrm{lb}$.; for all these babies the gestation periods lay between 30 and 34 weeks. The heaviest child was $4 \mathrm{lb} .1 \mathrm{oz}$., and five out of the sixteen cases were twin infants, the other twin having died or being unaffected. Since the number of babies under $3 \mathrm{lb}$. at birth who survive is very much smaller than the number of those between 3 and $4 \frac{1}{2} \mathrm{lb}$., these figures also show the greatly increased incidence of the disease in the lower birth weight groups.

\section{Aetiology}

So far the aetiology of the disease remains obscure. No common causative factor has been found in family history, maternal complications during pregnancy or at delivery, or in the neonatal treatment of the infant. Various suggestions have been made by different writers: 
(1) Persistence and Hyperplasia of the Hyaloid System.-The original suggestion of Terry (1942a, b) was that retrolental fibroplasia was due to a persistence and overgrowth of the hyaloid system. Owens and Owens (1949a) were the first to observe the disease developing in normal eyes in which the hyaloid system had completely atrophied, and their conclusion that the disease is not the result of overgrowth of a persistent tunica vasculosa lentis has since been amply confirmed (Reese and Blodi, 1951).

(2) Vitamin E Deficiency.-This was suggested by Owens and Owens (1949b) as a causative factor, and their earlier work appeared to give some encouraging results, if Vitamin $\mathrm{E}$ was given in the early stages. But their claims have not so far been substantiated, for both Reese and Blodi (1951) and Kinsey and Chisholm (1951) found that vitamin E administration made no significant difference to the incidence of retrolental fibroplasia if given from birth or early in the disease. Nor did withdrawing vitamin $\mathrm{A}$ and iron (which inhibit the availability of vitamin $E$ ) and giving vitamins $D$ and $C$ in water-miscible form have any effect (Kinsey and Chisholm, 1951).

(3) Oxygen Toxicity.-It has been suggested that premature babies. are unable to tolerate high oxygen concentrations in the incubator. Campbell (1951) quotes figures from Melbourne in support of this hypothesis-that 18.7 per cent. of 123 premature infants in high oxygen concentrations developed the disease, while only 6.9 per cent. of those in lower oxygen concentrations developed it. Further investigations of this are required.

(4) Deficiency of Adreno-Cortical Hormones. - Reese and Blodi (1951) have suggested that the condition is due to a deficiency of the adreno-cortical hormones. Their argument is as follows:

It is known that the mother's blood contains a large amount of these hormones during pregnancy, especially in the last 3 months. It is also known that cortisone prevents the growth of new blood vessels and decreases cellular exudation and capillary permeability. The premature infant may well be deficient in this hormone owing to its premature birth, and the angiomatous condition of retrolental fibroplasia may be allowed to develop unchecked. Hence ACTH, through its production of cortisone, may be of value in damping down these changes until such time as the baby's own adrenal cortex takes over.

In support of this theory, Reese and Blodi (1951) quote an increased incidence of skin haemangiomata in their cases of retrolental fibroplasia ( 15 per cent. as compared with 3 to 10 per cent. in unaffected premature infants). They also quote a post-mortem examination of a case of early retrolental fibroplasia where there was found to be a hypoplasia of the adrenal glands (for further discussion see under "Treatment" below).

It seems that while a deficiency of the adreno-cortical hormones may play an important part in the aetiology of the disease, there may well be some other factor of an infective, toxic or other nature still to be discovered.

\section{Clinical Course}

It has now been definitely established that babies who later develop retrolental fibroplasia are born with normal eyes-normal, at any rate, as far as ordinary 
external and ophthalmoscopic examination is concerned. Frequently the remnants of the hyaloid system are present at birth, but these usually disappear before the onset of the disease.

The clinical course can be divided into two stages:

(I) Acute, when the disease is active and rapidly progressive.

(II) Chronic, when organization and cicatrization occur.

The acute stage was first observed and fully described by Unsworth (1948) and by Owens and Owens (1949a). These observations were confirmed by Reese and Blodi (1951). The earliest changes consist essentially of dilatation of the retinal vessels and retinal haemorrhages, followed by subretinal oedema and neovascularization on the surface of the retina and in the vitreous. In this paper further detailed observations of these changes are made and the effect upon them of ACTH therapy is described.

Method of Examination.-Routine ophthalmoscopic examination has been carried out on all premature babies weighing under $4 \frac{1}{2} \mathrm{lb}$. at birth born in Bristol Premature Baby Units for 10 months. The baby is first examined between the 10th and 14th day, and thereafter at weekly intervals till the 8th week or later. The pupils are dilated with homatropine drops 1 per cent., no anaesthetic is used, and the fundi are examined in the dark using a baby speculum for lid retraction and a mains (6-volt) ophthalmoscope. No difficulty has been experienced in examining the whole fundus, including the extreme peripheries, by this method. At the age of 6 or 8 weeks the baby has become too restless and a general anaesthetic is usually required. All the fundus paintings have been recorded as seen from above the infant's head, as this is the position from which all infants have been examined in this series.

\section{Acute Stage}

(a) Preliminary Signs.-In this series of 57 babies of $4 \frac{1}{2} \mathrm{lb}$. or less at birth, four cases of early retrolental fibroplasia have been found. The onset of the disease usually occurs between the 3rd and 6th week of life, and all four cases described here developed the first signs of the disease in this period. The first signs are dilatation and tortuosity of the retinal vessels. The veins become enormously dilated (up to three times their normal calibre) and somewhat tortuous, while the arteries become less grossly dilated but extremely tortuous. Scattered superficial retinal haemorrhages were seen in one case only (Fig. 1(a)).

These changes are frequently reversible and are insufficient for a diagnosis of retrolental fibroplasia. In this series ten other babies developed a dilatation and tortuosity of retinal veins (twice or three times their normal calibre) and then reverted to normal without treatment. The time of onset is usually between the 10th day and the 5th week, but it may occur even later in the lowest birth weight groups-e.g., the 9th week in an infant of $1 \mathrm{lb} .14 \mathrm{oz}$. (Table II). The larger babies (over $3 \frac{1}{2} \mathrm{lb}$.) tended to develop the dilatation earlier (10th to 17th day), while the smaller babies (under $3 \frac{1}{2} \mathrm{lb}$.) developed it later (21st to 32 nd day or even later). But there were exceptions to this rule, e.g., Case 5 in Table II, where the dilatation was present on the 10th day in a baby of $3 \mathrm{lb} .4 \mathrm{oz}$. Two cases also developed peripheral tortuosities of the retinal veins (the stage immediately preceding that of new vessel formation) on the 18th and 19th days, but reverted to normal 2 weeks later without treatment. Case 2 in Table II is interesting. This baby (birth weight $2 \mathrm{lb} .15 \mathrm{oz}$.), the twin of one of the infants who developed the disease (P. F.), had normal fundi at $3 \frac{1}{2}$ weeks, dilated retinal veins at $4 \frac{1}{2}$ weeks, and 
TABLE II

PREMATURE INFANTS WHO DEVELOPED DILATED RETINAL VEINS BUT NOT RETROLENTAL FIBROPLASIA

\begin{tabular}{|c|c|c|c|c|c|c|}
\hline \multirow{3}{*}{$\begin{array}{l}\text { Case } \\
\text { No. }\end{array}$} & & & \multicolumn{3}{|c|}{ Age in weeks } & \multirow{3}{*}{ Other Features } \\
\hline & \multicolumn{2}{|c|}{$\begin{array}{c}\text { Birth } \\
\text { Weight }\end{array}$} & $\begin{array}{l}\text { When } \\
\text { first }\end{array}$ & $\begin{array}{l}\text { When } \\
\text { Dilatation }\end{array}$ & $\underset{\text { Reversion }}{\text { At }}$ & \\
\hline & lb. & oz. & Seen & noted & to Normal & \\
\hline 1. & 1 & 14 & $3 \frac{1}{2}$ & 9 & 11 & - \\
\hline 2. & 2 & 15 & $3 \frac{1}{2}$ & $4 \frac{1}{2}$ & 8 & Localized retinal oedema at $5 \frac{1}{2}$ weeks \\
\hline 3. & 3 & 3 & 3 & 4 & 8 & - \\
\hline 4. & 3 & 4 & 3 & 3 & 4 & - \\
\hline 5. & 3 & 4 & $1 \frac{1}{2}$ & $1 \frac{1}{2}$ & $4 \frac{1}{2}$ & $\begin{array}{l}\text { Peripheral tortuosities of veins at } \\
\text { 18th day } \\
\text { Congenital obstruction of bile ducts } \\
\text { Died at } 6 \text { weeks }\end{array}$ \\
\hline 6. & 3 & 6 & 2 & 4 & 6 & - \\
\hline 7. & 3 & 8 & $1 \frac{1}{2}$ & $1 \frac{1}{2}$ & 7 & - \\
\hline 8. & 3 & $11 \frac{1}{2}$ & $2 \frac{1}{2}$ & $2 \frac{1}{2}$ & 5 & $\begin{array}{l}\text { Peripheral dilatation and tortuosities } \\
\text { of veins at } 19 \text { th day }\end{array}$ \\
\hline 9. & 3 & 15 & $1 \frac{1}{2}$ & $1 \frac{1}{2}$ & $3 \frac{1}{2}$ & - \\
\hline 10. & 4 & 5 & 2 & 2 & 5 & - \\
\hline
\end{tabular}

further dilatation of veins and patches of localized retinal oedema near the disks at $5 \frac{1}{2}$ weeks. Then at $7 \frac{1}{2}$ weeks choroidal atrophy replaced the areas of oedema and at $8 \frac{1}{2}$ weeks the retinal veins became normal in calibre. The fundi are now within normal limits and the baby's vision appears to be normal. The larger twin (P. F.), 3 lb. 7 oz. at birth, was treated with ACTH but nevertheless developed the disease and is now blind (see under "Treatment" below).

(b) LATER Developments.-There now occur two changes which make the diagnosis of retrolental fibroplasia certain:

(1) New Vessel Formation (retinal and vitreous).

(2) Subretinal Oedema with Retinal Detachment.

These changes were first seen between $3 \frac{1}{2}$ and 6 weeks of age (Table III, overleaf).

(1) New Vessel Formation.--Reese and Blodi (1951) observed that this was a feature of the disease, but that it was sometimes difficult to detect in the absence of subretinal oedema. In this series no difficulty was experienced in detecting it in each case. It occurred in several different ways:

(i) Along the course of the main retinal veins, as tributaries splitting off and rejoining the main vein. This feature was well seen near the disk in Case 4 (Fig. 4(a)), and was also present in Case 1 (Fig. 1(a)), and in Case 3 (Fig. 3(a)), just before the area of retinal oedema in the periphery.

(ii) As new vessels related to areas of oedema, being buried in or surmounting these areas. These often have a corkscrew course as they cross the areas of subretinal oedema (Fig. 2(a)). 
TABLE III

AGE AT ONSET IN FOUR CASES OF EARLY RETROLENTAL FIBROPLASIA

\begin{tabular}{|c|c|c|c|c|c|c|c|}
\hline \multirow[t]{2}{*}{ Case } & \multirow[t]{2}{*}{ Sex } & \multirow[t]{2}{*}{$\begin{array}{l}\text { Date of } \\
\text { Birth }\end{array}$} & \multicolumn{2}{|c|}{$\begin{array}{l}\text { Birth } \\
\text { Weight }\end{array}$} & \multirow{2}{*}{$\begin{array}{l}\text { Duration } \\
\quad \text { of } \\
\text { Pregnancy } \\
\text { (weeks) }\end{array}$} & \multirow{2}{*}{$\begin{array}{c}\text { Age at } \\
\text { Onset of } \\
\text { Retrolental } \\
\text { Fibroplasia } \\
\text { (weeks) }\end{array}$} & \multirow[t]{2}{*}{ Comments } \\
\hline & & & lb. & oz. & & & \\
\hline $\begin{array}{l}\text { (L. G.) } \\
\text { (Figs 1 } \\
\text { and 5) }\end{array}$ & $\mathrm{F}$ & $20 / 2 / 51$ & 3 & 0 & 32 & 6 & $\begin{array}{l}\text { Retinal vessels nor- } \\
\text { mal at } 4 \text { weeks }\end{array}$ \\
\hline $\begin{array}{l}\text { 2. (P. F.) } \\
\text { (Figs } 2 \\
\text { and 6) }\end{array}$ & $\mathrm{F}$ & $13 / 5 / 51$ & 3 & $7 \frac{1}{2}$ & 32 & $3 \frac{1}{2}$ & $\begin{array}{l}\text { May have been } \\
\text { earlier } \\
\text { Baby unfit for } \\
\text { earlier examination }\end{array}$ \\
\hline $\begin{array}{l}\text { 3. (R. W.) } \\
\text { (Figs } 3 \\
\text { and } 7 \text { ) }\end{array}$ & $\mathbf{M}$ & $22 / 6 / 51$ & 3 & 8 & 32 & 5 & $\begin{array}{l}\text { May have been } \\
\text { earlier } \\
\text { Treatment deferred } \\
\text { till 6th week }\end{array}$ \\
\hline $\begin{array}{l}\text { 7. (C. B.) } \\
\text { (Figs } 4 \\
\text { and } 8 \text { ) }\end{array}$ & $\mathrm{F}$ & $28 / 7 / 51$ & 3 & 8 & 34 & 5 & $\begin{array}{l}\text { Retinal vessels ab- } \\
\text { normally thin at } \\
3 \text { weeks of age }\end{array}$ \\
\hline
\end{tabular}

(iii) As networks of new capillaries, which form in relation to areas of subretinal oedema in the periphery of the fundus. These tend to be most marked at the transition point from normal to detached retina, and are shown very clearly in Cases 1, 3, and 4 (Figs $1(b), 3(b), 4(b)$, and $4(c))$.

(iv) As new vitreous vessels budding off retinal veins. This occurs at the same time as the new capillary formation, or a little later. They bud at the areas of densest capillary network from the retinal surface into the vitreous at any angle. They usually originate from a large retinal vein, and have been easily visible in three cases. In Case 1 the vitreous vessels continued to grow as the capillary network on the retinal surface gradually subsided (Figs 1(b) and $1(c)$ ) between 11 and 14 weeks. In Case 2 a diffuse vitreous haze covering half the fundus between the 6th and 10th weeks of life made it impossible to see individual vitreous vessels (Fig. 2(b)) and only later did these become visible. In Case 3, as soon as ACTH was stopped at the 8th week, vitreous vessels started budding in one temporal quadrant (Fig. 3(b)) and continued to grow (Figs 3(c), 3(d)) until the 3rd month. They were also seen in Case 4 (Figs $4(b), 4(c)$ ) between the 9 th and 11 th weeks, and later as a free vitreous floater (Fig. $4(d)$ ). In three cases that were successfully treated, the vitreous vessels became obliterated at their origin from the retinal vein and were completely absorbed, normal fundi resulting between the 3rd and 4th month of life (Figs $1(d), 3(e), 4(e))$. In Case 4, a few new vitreous vessels appeared as soon as treatment was stopped at $11 \frac{1}{2}$ weeks, indicating that the disease was still active up to 3 months.

(v) As new vessels on the iris, which becomes vascularized as the disease becomes more active, so that it becomes difficult to dilate the pupil with mydriatics. This usually occurs about 2 weeks after the onset of the disease. In the three cases which responded to treatment, this vascularization gradually subsided, but it persisted longer in one which developed membranes (Case 2). Fig. 2(d) shows the appearance of the iris in Case 2 at the 3 rd month. 
(2) Subretinal Oedema with Retinal Detachment.-This appears to be an essential feature of the disease. It may occur initially (Figs 2(a), 3(a)) or at a later stage (Fig $4(c)$ ). It usually starts in both eyes as a localized circular patch or patches of oedema, resembling acute choroiditis, on the course of a main retinal vein, more frequently temporal than nasal, and, if peripheral, it spreads to involve half or the whole of the periphery of the fundus. The disease is always bilateral, but frequently more advanced in one eye than the other. This localized oedema must be distinguished from the generalized peripheral grey-white reflex present in the extreme periphery of the eyes of all premature infants (Figs 3(a)

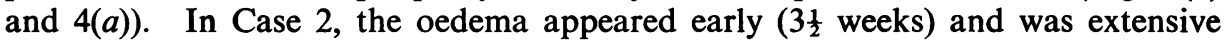
(Fig. 2(a)).

With treatment the oedema gradually subsided, and areas of choroidal atrophy (Fig. 2(b)), choroidal thinning (Fig. 4(e)), or normal fundi (Figs 1(d), 3(e)) were left. If untreated, cases have been seen to go on to develop total retinal detachment from the enormous increase in this oedema (Owens and Owens, 1949a), and one of our treated cases did this (Case 2).

There appears to be a definite connection between the new vessel formation and the subretinal oedema. Whatever factor is responsible for the disease appears to act simultaneously on both retinal and choroidal circulations, causing dilatation of the retinal vessels and new vessel formation on the one hand, and subretinal oedema from increased capillary permeability on the other. In Cases 2 and 4 it could be observed that as the new vessel formation and oedema subsided near the posterior pole, the changes in the anterior half of the retina and the iris became more marked, as if the disease was moving more anteriorly.

\section{Chronic Stage}

Organization AND Fibrosis.-The development of this stage has been fully described by Owens and Owens (1949a) and by Reese and Blodi (1951). Both the increasing subretinal oedema and the organizing vascularization of the vitreous tend to cause retinal detachment, and a complete retrolental membrane is formed by a combination of these factors.

This stage has been seen to develop in only one of our four early treated cases. This was in Case 2, where between the 6th week and 3rd month the invasion of the vitreous by a dense network of fine capillaries was associated with increasing subretinal oedema in the same (nasal) half of the fundi. By the 3rd month retinal detachment and fibrosis of the vitreous had, despite treatment, gradually filled the nasal half of the globe from the ciliary region back to the disk (Figs $2(c), 2(d)$ ), while an atrophic retina with pigmentary changes and very attenuated retinal vessels was still visible in the temporal half of both eyes (Fig $2(c)$ ). The process of vascularization and fibrosis gradually extended to fill the whole vitreous, and the temporal retina was obliterated by the 4th month in one eye and by the 5th month in the other. At the same time (3rd to 5th month) the anterior chamber became shallow and the iris atrophic, and the globes shrank. The late, or cicatricial, stage had now been reached.

\section{Differential Diagnosis}

(I) Early Stage.-The only difficulty here is to decide when progressive retrolental fibroplasia is present, as opposed to dilatation and tortuosity of the retinal vessels, with or without haemorrhage, which may be self-limiting. Further observation without treatment is advisable in cases of doubt. 
(II) Late (Cicatricial) Stage.-In the late stage of formation of complete retrolental membranes, the disease must be distinguished from several other conditions.

(i) Retinoblastoma (Glioma of the Retina).--Retinoblastoma has no association with prematurity. In bilateral retinoblastoma, where the tumours fill the vitreous chambers, the globe is of normal size, the tension normal or raised, the anterior segment usually normal, and the surface of the " membrane" often nodular.

In retrolental fibroplasia, on the other hand, the globe is often microphthalmic, the tension soft, the anterior chamber shallow, and the iris atrophic; posterior synechiae are present, and the membrane is smooth and vascularized.

(ii) Pseudoglioma.-It seems likely that some cases previously diagnosed as pseudoglioma were in fact cases of retrolental fibroplasia. Pseudogliomata are inflammatory in origin and include such conditions as tuberculous uveitis and metastatic endophthalmitis. Previous signs of inflammation, including keratic precipitates, are always present, and the condition has no direct association with prematurity.

(iii) Persistence and Hyperplasia of the Hyaloid System.-The condition is usually unilateral and occurs in full-term infants. A complete retrolental membrane may be formed because of a persistence of the hyaloid artery and posterior part of the fibrovascular sheath of the lens. The vitreous chamber may be filled with fibrosis from overgrowth of the primary vitreous (see Reese (1949) for further discussion).

(iv) Dysplasia of the Retina (Krause, 1946; Reese and Blodi, 1950).-This is a bilateral condition occurring in full-term infants and is part of a general encephaloophthalmic dysplasia. It is associated with many other congenital abnormalities, especially in the brain, cardio-vascular system, and skeleton. Mental retardation is common.

\section{Treatment with ACTH}

(A) Review of Literature.-The largest series of cases treated with ACTH so far reported is that of Reese and Blodi (1951) who treated a series of fourteen early cases. They gave $20-25 \mathrm{mg}$. ACTH daily for 14 days, and a second course was given in two cases which relapsed on stopping treatment. Of these fourteen cases, none developed retrolental membranes. Some had normal fundi, and some had white masses of tissue far in the periphery. In a similar series of eight cases, which were untreated, three developed complete membranes, three developed partial membranes, and two had white masses of tissue in the periphery of the fundi.

Scheie and others (1951) reported five cases, but only two of these, as the authors point out, gave reliable data as to the value of ACTH in the disease. Of the five cases, one died, one was given insufficient treatment, and one was too old before treatment was started ( 5 months). Of the remaining two, one was a failure, and one a success. One case was that of a baby of $2 \frac{1}{4} \mathrm{lb}$. at birth who had signs of severe retrolental fibroplasia at the 72nd day. ACTH was given in doses of $10 \mathrm{mg}$. per day, increased to $20 \mathrm{mg}$. per day 4 days later. Despite this, the baby developed bilateral membranes. The other, an infant of $4 \mathrm{lb}$. $2 \mathrm{oz}$. at birth, developed early retrolental fibroplasia at the 24th day, and was treated with $8 \mathrm{mg}$. ACTH per day for 14 days; the condition settled and the fundi became normal. Other observers report little success. McLean and others (1951) treated five 
cases with $25 \mathrm{mg}$. ACTH per day: two were fully developed before treatment and were not affected; three were early, and of these two appeared to regress, though one of them relapsed after treatment was stopped (re-institution of treatment might have been of value in this case). Fitzgerald and others (1951) reported three cases treated with $3 \mathrm{mg}$. ACTH per day. Treatment was started at 2 months in one case and at 1 month in the two others. No improvement was found in any case (dosage here appears to have been rather small). Woods $(1950,1951)$ reported five cases treated with 25 to $40 \mathrm{mg}$. per day with no improvement. No further clinical details are given by the last three observers. In the absence of data on birth weight, age at onset of disease and at start of treatment, and duration of treatment, it is difficult to make an accurate assessment as to the value of ACTH in treatment. It is possible that earlier or more continued treatment, or larger doses of ACTH might have given better results. It is significant that in the successful cases reported, treatment was always started early, usually between the 3rd and 5th week. These findings are supported by the cases now to be described.

\section{(B) Description of Authors' Cases and Treatment}

(1) General Care.-The routine method of nursing and feeding was used for all the cases described. All the infants were nursed in oxygen incubators or in the Queen Charlotte's Hospital type infant's oxygen tent; the rate of flow and length of time in oxygen depended on the general condition of the baby. Feeding is begun at a varying time after birth according to the child's " demand ". Human milk, diluted for the first 3 to 4 days, is given for 14 to 20 days, when, if the infant is not breast-fed, a gradual change-over takes place to Frailac (a proprietary dried milk with low protein and fat and high sugar content). At approximately $5 \frac{1}{4}-5 \frac{1}{2} \mathrm{lb}$. another gradual change to a half-cream dried milk is made. Synthetic vitamin $\mathrm{K} 10 \mathrm{mg}$. is given 8-hourly for the first 5 days, at first intramuscularly and subsequently by mouth. Vitamins A and D are started on the 7th day in gradually increasing doses up to 2,250 units vitamin $D$ daily by the 17 th day. Ascorbic acid $5 \mathrm{mg}$. is also started on the 7 th day and the dose is increased by $5 \mathrm{mg}$. daily up to $50 \mathrm{mg}$. daily. The only other diet supplement received normally is iron, which is started at 4 weeks of age, the routine preparation used being "Neoferrum ", dose 1 minim daily, increasing gradually up to 5 minims by 2 months.

All the cases described had no evidence of any congenital abnormalities, and have shown no tendency to develop cutaneous angiomata.

(2) Treatment of Advanced Retrolental Fibroplasia.-Treatment with ACTH was tried first on Cases 9 and 11 (Table I). Case 9 had bilateral advanced membranes and appeared totally blind. She was aged 7 months. The eyes showed shallow anterior chambers, atrophic irides, posterior synechiae, and microphthalmos. The dosage employed was $12.5 \mathrm{mg}$. 6-hourly, and this was continued for 14 days and subsequently reduced to half dose. Treatment over a period of 4 weeks produced no alteration in the eye condition.

Simultaneously Case 8, who was approximately the same age, had a complete retrolental membrane in the right eye, with a normal anterior segment; in the left eye there was a vitreous band running from the disk to the ciliary region on the temporal side. This baby was given cortisone by 
injection, $50 \mathrm{mg}$. twice daily, continuously, but in tapering dosage, for 4 weeks, and was then restarted for a further fortnight after a short interval. No change was seen in the eye condition during this period. Both these children have been observed regularly since. Their general development is satisfactory, but unilateral microphthalmos has developed in Case 8 and apart from some perception of light in this case, they appear quite blind.

Case 11 lived some distance from Bristol so that only very infrequent visits were made to the follow-up clinic. Just before the age of 5 months, opacity of the left pupil was noticed by the mother, and the child was seen by an ophthalmic surgeon, who removed the eye as a possible case of glioma. The section confirmed the diagnosis of retrolental fibroplasia. She was seen by us about 4 weeks later. There was coarse nystagmus in the right eye, and two retinal septa and three vitreous bands were evident. She was treated with ACTH $50 \mathrm{mg}$. daily for 4 weeks, which was then reduced to half dosage for a further 4 weeks. There was slight improvement in the condition at the end of this period, one retinal septum being absorbed. This may have been a spontaneous change, since some further clearing of the vitreous bands occurred by the age of 15 months. At present, at the age of 18 months, this child is healthy, well-developed mentally, and has some limited vision.

. A surgical removal of the membrane was attempted in Cases 9 and 12 (Table I). As described by Reese (1949) and Reese and Blodi (1951), a scleral incision was made and a fine hook was introduced behind the lens. An attempt was made to draw the membrane out of the pupil, but no improvement was obtained in either case.

These first three cases were all closely watched for evidence of metabolic disturbances. Daily weighing showed that after a few days of normal gain the weight tended to remain stationary throughout the period of treatment and that appetite was capricious towards the end of treatment. Daily eosinophil counts showed definite reduction in Case 11, but no obvious changes in the other two patients. There was no glycosuria and no significant effects on blood sugar. Daily serum sodium and potassium estimations were made and showed no gross alterations. It was therefore considered unnecessary to make these somewhat time-consuming observations on subsequent patients. After cessation of treatment, all appeared to make satisfactory physical and mental progress. Two other advanced cases with obvious bilateral membrane have also been treated, but in view of the negligible result in such cases treatment was abandoned after 2 weeks.

(3) Treatment of Early Retrolental Fibroplasia

(i) General Effect of ACTH (intramuscular).-Four early cases will now be described in detail (Table IV). The effect of the preparation on the general condition of the babies was not evident for a few days, but weight gain and developmental progress then appeared to be slower than normal during the period of treatment. The typical "moon-face" developed in each case after about four weeks and at the same time the child became less 
TABLE IV

RESULTS OF TREATMENT WITH ACTH IN FOUR CASES OF EARLY RETROLENTAL FIBROPLASIA

\begin{tabular}{|c|c|c|c|c|c|c|c|c|c|c|}
\hline \multirow{3}{*}{ Case } & \multirow{3}{*}{ Sex } & \multirow{3}{*}{$\begin{array}{l}\text { Date of } \\
\text { Birth }\end{array}$} & & & \multirow{2}{*}{\multicolumn{2}{|c|}{$\begin{array}{l}\text { Dosage of } \\
\text { ACTH } \\
\text { (mg.) }\end{array}$}} & \multicolumn{3}{|c|}{ Treatment } & \multirow{3}{*}{ Result } \\
\hline & & & \multicolumn{2}{|c|}{$\begin{array}{l}\text { Birth } \\
\text { Weight }\end{array}$} & & & \multirow{2}{*}{$\begin{array}{l}\text { Age } \\
\text { at Start } \\
\text { (weeks) }\end{array}$} & \multirow{2}{*}{$\begin{array}{c}\text { Duration } \\
\text { (weeks) }\end{array}$} & \multirow{2}{*}{$\begin{array}{l}\text { Age at } \\
\text { Cessa- } \\
\text { tion } \\
\text { (weeks) }\end{array}$} & \\
\hline & & & lb. & oz. & Daily & Total & & & & \\
\hline $\begin{array}{l}\text { 1. (L. G.) } \\
\text { (Figs 1 } \\
\text { and 5) }\end{array}$ & $\mathbf{F}$ & $20 / 2 / 51$ & 3 & 0 & $20-25$ & 1,050 & $7 \frac{1}{2}$ & 6 & 14 & Normal fundi \\
\hline $\begin{array}{l}\text { 2. (P. F.) } \\
\text { Figs } 2 \\
\text { and 6) }\end{array}$ & $\mathbf{F}$ & $13 / 5 / 51$ & 3 & $7 \frac{1}{2}$ & $20-40$ & 2,440 & $3 \frac{1}{2}$ & 10 & $13 \frac{1}{2}$ & $\begin{array}{l}\text { Bilateral } \\
\text { membranes }\end{array}$ \\
\hline $\begin{array}{l}\text { 3. (R. W.) } \\
\text { (Figs 3 } \\
\text { and 7) }\end{array}$ & $\mathbf{M}$ & $\begin{array}{c}22 / 6 / 51 \\
.\end{array}$ & 3 & 8 & 25 & 1,050 & 6 & 5 & 12 & Normal fundi \\
\hline $\begin{array}{l}\text { 4. (C. B.) } \\
\text { (Figs } 4 \\
\text { and } 8 \text { ) }\end{array}$ & $\mathbf{F}$ & $28 / 7 / 51$ & 3 & 8 & $20-25$ & 1,414 & 5 & 11 & 17 & $\begin{array}{l}\text { Normal fundi ex- } \\
\text { cept for white } \\
\text { tissue in far peri- } \\
\text { pheries }\end{array}$ \\
\hline
\end{tabular}

active, less interested in food, and easily irritated; colour became sallow although there was no obvious anaemia, and although the volume of urine was not actually measured the nursing staff commented on the large quantity the infants appeared to be passing. Two cases developed attacks of head jerking and twitching of the limbs, suggestive of minor convulsions. The blood pressure was only taken regularly in the most recent case, and here after 5 weeks' treatment the systolic pressure was $270 \mathrm{~mm}$.

After cessation of treatment very rapid gain in weight and skeletal growth occurred, so that by the age of 6 months the children were of comparable size with other children in the same birth weight group. In three of the four cases mental development progressed rapidly also and appeared normal, but the child who required the higher dosage is still retarded compared with her twin. The twitching movements persisted for about 4 weeks but have now ceased completely. The case with hypertension has resumed a systolic blood pressure of $85 \mathrm{~mm}$. after 6 weeks.

(ii) Progress in Individual Cases.-The early signs of progressive retrolental fibroplasia were present before the start of treatment in each case. The presence of Stage I(a) was not considered to be an indication for starting treatment, as this stage is known to be reversible. When the disease had progressed to Stage I(b) (localized subretinal oedema and new vessel formation), this was taken as an indication for starting treatment. 


\section{Case Reports}

\section{Case 1, L. G., female, born February 20, 1951 (Figs 1 and 5)}

(1) General Progress before Treatment.-The mother, aged 32, had had three previous pregnancies: in 1942, after 38 weeks' gestation, a forceps delivery of a healthy child, in 1944 a full-term normal child, and in 1945 a miscarriage at 8 weeks. Her blood group was $\mathrm{A} R \mathrm{Rh}$ positive with no abnormal antibodies. On this occasion she had severe pre-eclamptic toxaemia for which Caesarean section was performed at 32 weeks using pentothal, cyclopropane, and oxygen anaesthesia, which was administered for 15 minutes before delivery. The infant, who weighed $3 \mathrm{lb}$., length $16 \frac{1}{2}$ ", head circumference $11 \frac{1}{2}$ ", was severely asphyxiated at birth. After one initial gasp she failed to breathe for 5 minutes, and resuscitative measures included intravenous lobeline gr. 1/40 and oxygen: respirations were established in about 10 minutes but were rapid, shallow, and irregular for the first $24 \mathrm{hrs}$, and generalized twitching occurred when the baby was disturbed. She was nursed in an incubator with oxygen flow of 2 to 3 litres per minute for 28 days. On the 3rd day she became jaundiced and subsequently developed a few pustules on the skin of the neck, whence Staph. aureus was cultured. Distaquaine 150,000 units twice daily intramuscularly was started on the 5 th day and given for 5 days. The jaundice became very marked on the 6th day, and her condition became very poor with a tendency to cyanotic attacks, and some dehydration. She was therefore given Darrow's solution $100 \mathrm{ml}$. subcutaneously with hyalase during the next $24 \mathrm{hrs}$. Her haemoglobin at this stage was $122 \mathrm{mg}$. per cent. and her blood bilirubin $20 \mathrm{mg} . / 100 \mathrm{ml}$. Feeding was started by oesophageal tube at $67 \mathrm{hrs}$ with diluted human milk. During this first week body temperature fluctuated between $96^{\circ}-99^{\circ}$ and the infant remained lethargic and unable to suck. On the 14th day she developed a small abscess on her thigh and was therefore given a second similar course of Distaquaine. On the 18th day her haemoglobin had decreased to 46 per cent. Her blood group was A Rh negative, and direct Coombs test was negative. She was given a transfusion of $45 \mathrm{ml}$. packed blood, cells Group A Rh negative. Following this her general condition greatly improved and on the 20th day weaning from human milk to Frailac was begun. On the 22nd day it was noticed that she did not respond normally, by blinking, to a light shone on her eyes. She was by now making very steady weight gain, but bottle feeding was not possible until the 37th day and tube feeding was accordingly not abandoned until the 46th day. The change to half-cream Cow and Gate was begun on the 52nd day and completed by the 64th day. The usual vitamins and iron supplements were given.

(2) Eye Progress during Treatment

(a) Clinical Picture before Treatment.-At 4 weeks, the fundi were within normal limits for a premature baby. The retinal vessels were normal, and there was the usual peripheral grey-white reflex in both eyes.

At 6 weeks, early retrolental fibroplasia was present, with very dilated retinal veins (three times their normal calibre), moderately dilated and tortuous arteries, peripheral corkscrew tortuosities of the veins, new vessel formation along the course of the main retinal veins, and increased peripheral subretinal oedema (Fig. 1a). At $7 \frac{1}{2}$ weeks (April 12, 1951) the condition had progressed, and the irides had become vascularized. A course of ACTH $20 \mathrm{mg}$./day was therefore started and given for 2 weeks.

(b) Effect of Treatment.-All the above changes decreased, except for the retinal veins, which remained grossly dilated. As the disease was apparently under control, treatment was stopped at $9 \frac{1}{2}$ weeks.

(c) Effect of stopping Treatment.-The condition in both eyes promptly relapsed, and the resulting fundus changes seen 4 days later are shown in Fig. 1b. A dense capillary network on the retinal surface developed in the temporal periphery of both eyes, with an increase in subretinal oedema in that area and an overlying vitreous haze. In one quadrant vitreous vessels could be seen starting to bud. 
(d) Effect of restarting Treatment.-Full treatment was restarted at 10 weeks. There was a gradual subsidence of all these signs, except for the growth of the vessels into the vitreous, mainly in the temporal periphery. The subretinal oedema and capillary network gradually subsided in the next 3 , weeks, but the vitreous vessels continued to grow larger (Fig. 1c). One isolated vessel grew half way between the disk and temporal periphery (Fig. 1c), and, like the others, originated from a main retinal vein. By the 3rd month the retinal background was normal and a thinning of the base of the vitreous vessels occurred. Treatment was then stopped, and by the 5th month all trace of the vitreous vessels had disappeared and the fundi were completely normal (Fig. 1d). This baby, now aged 9 months, has normal fundi and, as far as can be judged at this age, normal vision.

(3) General Progress during Treatment (Fig. 5).-ACTH $5 \mathrm{mg}$. 6-hourly was started on April 12, 1951. Her weight was then $5 \mathrm{lb} .10 \mathrm{oz}$. As her haemoglobin had again dropped to 60 per cent., a blood transfusion of $80 \mathrm{ml}$. was given on the same day. 


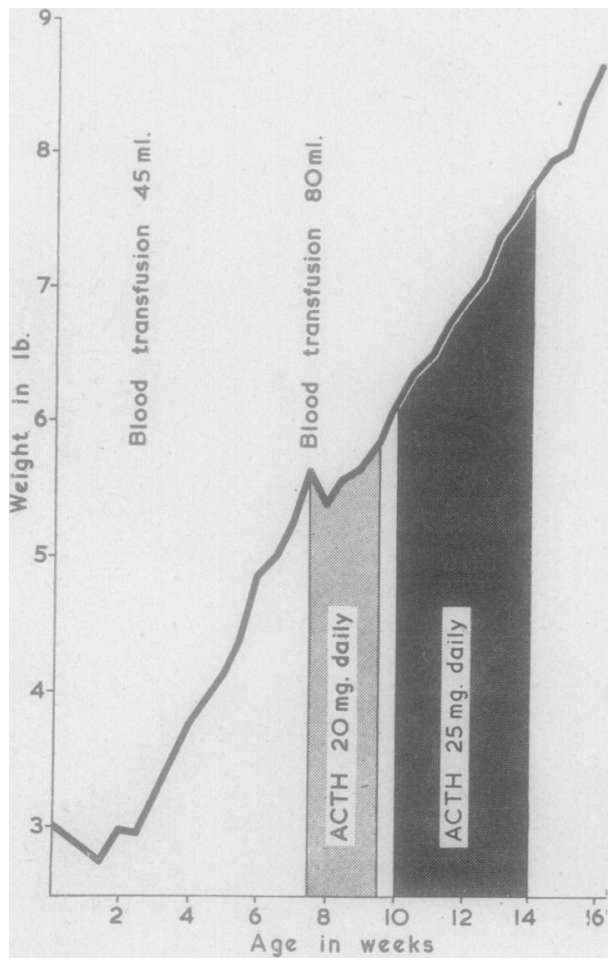

Fic. 5.-Case 1 (L. G.)

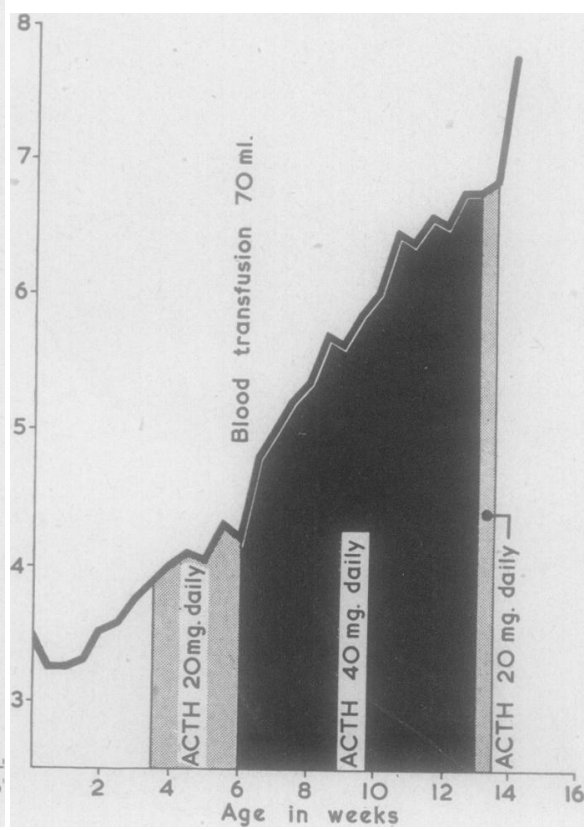

FiG. 6.-Case 2 (P. F.)

During the first week of treatment the infant remained active with good appetite but lost $4 \mathrm{oz}$. in weight and was considered to be passing rather more urine than previously. This was examined on several occasions but showed no abnormality. Subsequently, the baby became more restless, and less hungry, and gained $5 \mathrm{oz}$. in 4 days.

On restarting treatment on the $71 \mathrm{st}$ day, with $25 \mathrm{mg}$. daily, the infant lost $3 \mathrm{oz}$. in weight during the first 3 days, but subsequently started to gain steadily. During this period she began to develop a fullness of the lower part of the face and remained rather pale. She started to hold her head up but was noticed to be rather stiff in the neck and tense when handled. Her appetite was very good and she was generally active, although a week later she was definitely irritable. Subsequently, her face became more swollen and she was very irritable and stiff.

On May 28, 1951, ACTH was discontinued after a total dosage of $1,050 \mathrm{mg}$. The child remained well, became less irritable, and began to gain weight more rapidly.

On June 4, 1951, she was discharged home aged 104 days. Weight $8 \mathrm{lb} .10 \mathrm{oz}$, length 21", head 13" in circumference. Four weeks later her pupils reacted to light. There was a tendency to irregular spasmodic movements of head and limbs, and nystagmoid movement of the eyes were very marked, but she was able to follow lights and moving objects.

At 6 months, her general condition was very good. Weight $12 \mathrm{lb}$. $6 \frac{1}{2} \mathrm{oz}$., length $23 \frac{1}{2}$ ", head 16". She had a good appetite and was starting solid feeding normally. She held her head up well, smiled, and rolled from supine to prone position. Seemed very interested in surroundings and people, and appeared to make attempts to look at and grasp objects held in front of her. Some twitching movements of head and limbs were noticed occasionally. 
On November 20, 1951, aged 9 months, weight $15 \mathrm{lb}$. $14 \mathrm{oz}$., length 26", head 171". She seemed a normal healthy child, with good colour, two teeth, fontanelle about normal, firm muscle tone, and no twitching movements noticed. She was feeding well and was able to sit with slight support, grasped and touched objects within reach, followed moving objects with her eyes and reached for them.

\section{Case 2, P.: F., female, first of twins, born May 13, 1951 (Figs 2 and 6)}

(1) General Progress before Treatment.-The mother, aged 24, a healthy woman, was in labour $27 \mathrm{hrs}$, during which she was given pethidine $100 \mathrm{mg}$. and gas and air analgesia. This child was delivered by forceps after 32 weeks' pregnáncy. Weight $3 \mathrm{lb}$. $7 \frac{1}{2} \mathrm{oz}$., length $16^{\prime \prime}$, head circumference $11 \frac{1}{2} "$. There was slight asphyxia which responded well to oxygen, although signs of atelectasis persisted for 3 days, and therefore prophylactic penicillin was given. There was some generalized oedema for $48 \mathrm{hrs,}$ and a mild left facial palsy which cleared up completely. She was nursed in an oxygen tent with an oxygen flow of 2.5 litres per minute for 7 days. Her temperature was stable, and feeding followed the normal routine, starting with human milk and later changing to Frailac and then half-cream dried milk. Moderate jaundice appeared on the 2nd day and on the 11th day she developed slight skin sepsis which cleared in 5 days. Her condition was satisfactory in every way when, on the 25 th day of life, early retrolental fibroplasia was diagnosed.

\section{(2) Eye Progress during Treatment}

(a) Clinical Picture before Treatment.-At the 25th day (June 7, 1951) early retrolental fibroplasia was present (Fig. $2 a$, overleaf). There were dilated, tortuous retinal veins (twice their normal calibre), and tortuous retinal arteries. Patches of subretinal oedema resembling acute choroiditis covered the posterior poles of both fundi, and there were tortuous new vessels near the disks crossing these areas. There was a marked increase in subretinal oedema all round the periphery of the fundi.

(b) Effect of Treatment.-ACTH $5 \mathrm{mg}$. 6-hourly was started immediately (June 7, 1951). At $5 \frac{1}{2}$ weeks (June 21,1951$)$ there was a subsidence of the patches of subretinal oedema at the posterior pole, but a vitreous haze developed from the nasal side of both disks over the whole nasal half of each retina (Fig. $2 b$ ). Probably a massive growth of fine new capillaries took place into the vitreous (not visible with the ophthalmoscope) and at the same time there was probably an increase in the subretinal oedema. Dosage was then increased to $10 \mathrm{mg}$. 6-hourly, but despite this, by 3 months, an extensive nasal detachment had developed in both eyes with fibrosis of the vitreous in that area, secondary to vascularization of the vitreous (Figs $2 c$ and $d$; the latter shows an oblique view of the nasal membrane by focal illumination). As this nasal membrane formed, some large retinal vessels could be seen entering the vitreous from the edge of the remaining retina. A thin vertical veil of fibrous tissue, partly pigmented, covered the disk, and on the temporal side of this veil there was still a retina visible, but one which was atrophic and on which the retinal vessels were very thin (Fig. $2 c$ ). There was a network of fine vessels ramifying on the nasal membrane. Gradually, between the 3rd and 5th month, there was an extension of fibrosis of the vitreous over the remaining retinae to form complete retrolental membranes, and all red reflex was lost (Fig. 2e).

The baby has now at 7 months the appearance of fully developed retrolental fibroplasia, with small eyes, shallow anterior chambers, atrophic irides, but no posterior synechiae, and bilateral retrolental membranes with some fine vessels on them.

In this case there was some'doubt as to the activity of the batch of ACTH used in the first few weeks of treatment, as the baby continued to gain weight despite full doses of the drug. A fresh supply was used 2 weeks later, but it is possible that by then certain irreversible changes had already occurred in the vitreous. 


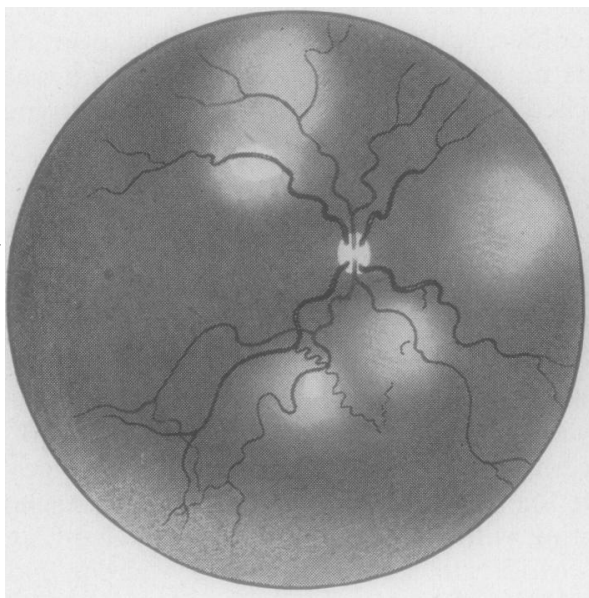

(a) $3 \frac{1}{2}$ weeks

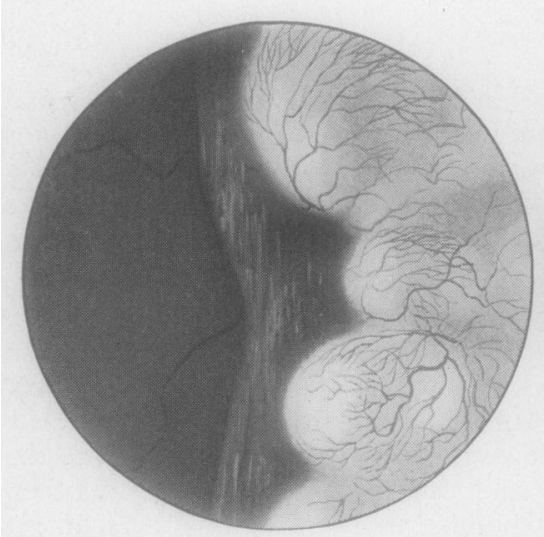

(c) 13 weeks

FIG. 2.-Case 2 (P. F.), left fundus viewed from above $(a),(b)$, $(c)$; left eye: external appearance from temporal side $(d)$; left eye: external appearance from in front (e).

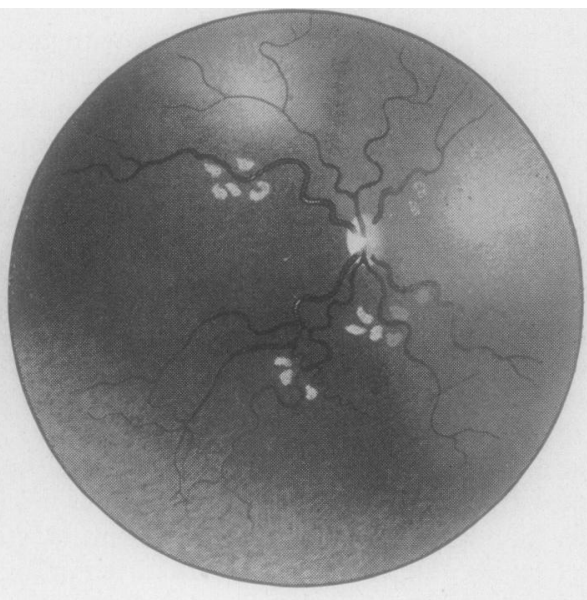

(b) $5 \frac{1}{2}$ weeks
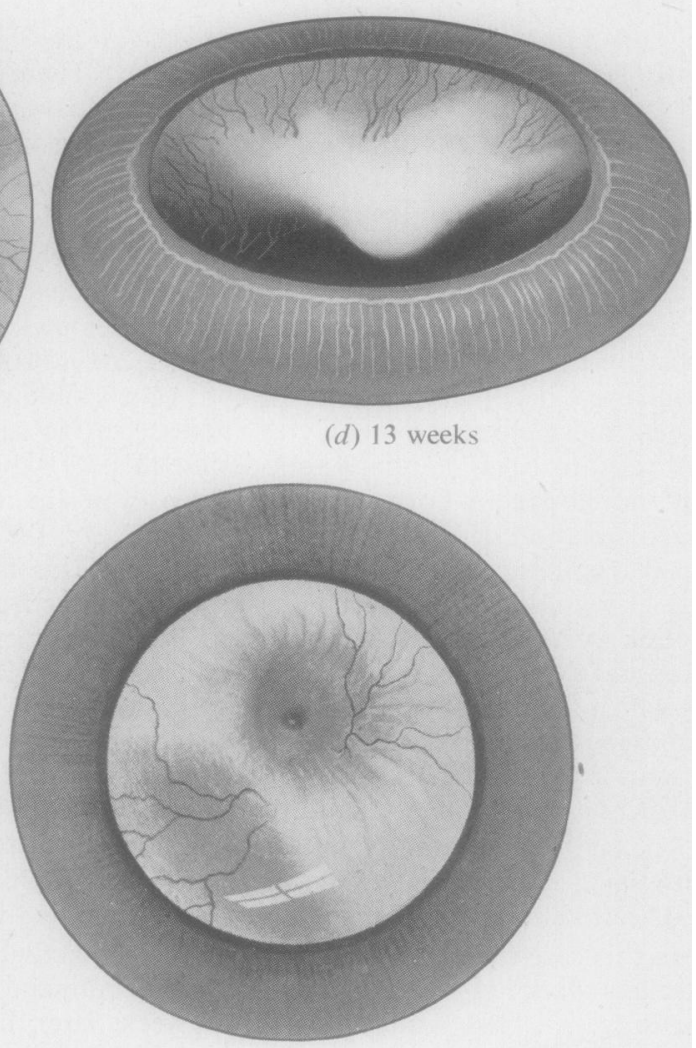

(e) 21 weeks 
(3) General Progress during Treatment (Fig. 6).-At the start of treatment, her weight was $3 \mathrm{lb} .13 \mathrm{oz}$. and haemoglobin 66 per cent. During the following week her weight remained stationary for 14 days and then began to rise. As the haemoglobin dropped to 56 per cent. a blood transfusion of $70 \mathrm{ml}$. packed cells was given on June 20 , 1951. The next day the dose of ACTH was increased to $10 \mathrm{mg}$. 6-hourly, but despite this increase, she continued to gain weight and seemed very active for the first week and then the rate of gain was slowed down. Treatment was continued, but appeared to have little effect on the general state of the baby during the next fortnight. She started to gain weight again, fed very well, and developed some puffiness of the lower face. After a further 10 days there was another cessation of weight gain for a fortnight, despite adequate food intake and adequate progress otherwise.

On August 13, 1951, ACTH dosage was reduced to $10 \mathrm{mg}$. twice daily for 3 days when it was discontinued. Altogether $2,440 \mathrm{mg}$. ACTH were given over 68 days. On cessation of treatment at 95 days, her weight was $7 \mathrm{lb}$. $10 \frac{1}{2} \mathrm{oz}$., length $20^{\prime \prime}$, head circumference $14 \frac{1}{2}$ ". After cessation of treatment there was a rapid gain in weight but the child remained with puffy face for about 4 weeks, and was also inclined to get bouts of irregular jerky movements of the head and limbs when disturbed. She made no attempt to smile. At 5 months she was smiling but not so responsive to stimulation as the other twin and not holding her head up well. She had no nystagmus.

By November 15, 1951, at 6 months, her weight was $12 \mathrm{lb} .3 \mathrm{oz}$., length $23 \frac{1}{2}{ }^{\prime \prime}$, head circumference 16", and the general condition was very good. She now follows a light and holds her head up, but makes no attempt to grasp objects. Her face has resumed its normal contour and all jerking movements have ceased.

This patient's twin has already been mentioned (Table II, Case 2); her general physical and mental development is definitely about 4 weeks more advanced.

\section{Case 3, R. W., male, first of twins, born June 23, 1951 (Figs 3 and 7)}

(1) General Progress before Treatment.-The mother, aged 26, was a healthy woman who had had one previous normal full-time child. During labour, which lasted $3 \mathrm{hrs}$, she was given pethidine $100 \mathrm{mg}$. and gas and air analgesia. The delivery after a pregnancy of 32 weeks was by the vertex and the child showed no evidence of asphyxia. His weight was $3 \mathrm{lb}$. $8 \mathrm{oz}$., length 16", head circumference 11 $\frac{1}{2}$. His condition after birth was very good, and the lungs expanded rapidly, but there was slight generalized oedema for the first $48 \mathrm{hrs}$. On the 3rd day slight jaundice developed. He was nursed in an oxygen tent, with an oxygen flow of 2 litres per minute for 13 days. His temperature for the first 14 days was variable, from $96^{\circ}-99^{\circ}$; subsequently it settled to an average of $97^{\circ}-98^{\circ}$. On the 3rd day a very mild conjunctivitis developed, it was treated with guttae penicillin for $48 \mathrm{hrs}$, and on the 12th day recurred (Staph. aureus). On the 24th day he inhaled some feed and was treated prophylactically with penicillin 30,000 units 3-hourly intramuscularly for $24 \mathrm{hrs}$, followed by Distaquaine 150,000 units twice daily for 3 days, to which he rapidly responded. Feeding and diet supplements were given according to the usual routine for artificial feeding.

(2) Eye Progress during Treatment

(a) Clinical Picture before Treatment.-The fundus, examined on July 26, 1951 (34th day), revealed early retrolental fibroplasia (Fig. $3 a$, overleaf). The retinal veins were very dilated ( $2 \frac{1}{2}$ times their normal calibre) and the arteries extremely tortuous. There was early localized subretinal oedema in the peripheries along the course of the main retinal veins, and the veins here became tortuous and elevated as they crossed the patches of oedema. New vessel formation on the retinal surface was present just anterior to the patch of oedema. The changes were most marked in the temporal peripheries.

By the 6th week (August 2, 1951) the condition had progressed, and all the above changes had increased. The irides were slightly vascularized and the pupils dilated less well with homatropine. 
(b) Effect of Treatment.-A course of ACTH, $25 \mathrm{mg}$. daily, was started on August 2, 1951. After 2 weeks' treatment (6th-8th week) there was a subsidence in the early signs, though the veins remained very dilated. There were still patches of localized oedema in the peripheries crossed by tortuous veins, though these patches were smaller than before. As the condition appeared to be under control, treatment was stopped (August 18, 1951).

(c) Effect of stopping Treatment.-Four days later (August 22, 1951), the condition had relapsed in both eyes, more in the left than in the right, and the resulting fundus changes in the worse eye at 9 weeks are shown in Fig. $3 b$. Extensive subretinal oedema developed in the whole of the temporal periphery and to a less extent in the rest of the peripheral fundus. There was much new vessel formation on this area of oedema, and three vitreous vessels started budding in one quadrant.

(d) Effect of restarting Treatment.-On August 22, 1951, treatment was started again in the same dosage. During the next few weeks there was a gradual subsidence in the signs of active disease. The condition at 10 weeks is shown in Fig. 3c. The subretinal oedema had again become localized, and most of the new vessels which had appeared on stopping treatment had disappeared again. The three vitreous vessels in one quadrant had grown larger. The irides remained slightly vascularized.

By the 12th week the clinical picture had further improved (Fig. 3d). The retinal veins had become of normal calibre. The localized subretinal oedema had disappeared and had been replaced by a tangled network of vessels on the retinal surface. The three vitreous vessels had grown longer but their base was becoming thinner. The irides were now not vascularized and the pupils dilated normally with homatropine.

As the disease appeared to have passed its period of activity, treatment was stopped, and no relapse occurred. The total dose of ACTH given was $1,050 \mathrm{mg}$.

By the 4th month the fundi had become completely normal (Fig. 3e), and all trace of abnormal vessels had disappeared. The baby, now 6 months old, has normal fundi, and, as far as can be judged, normal vision.

(3) General Progress during Treatment (Fig. 7).-During the first 14 days his weight remained almost stationary despite continued normal feeding. During the second course of treatment he gained $10 \mathrm{oz}$. in 3 weeks and developed considerable swelling of the lower face. He remained slightly lethargic and made no developmental progress but fed quite well.

After discontinuation of ACTH more rapid weight gain was observed and the facial swelling gradually subsided. Some undue irritability was noticed and a tendency to jerky limb movements when he was disturbed. On November 5, 1951, at 18 weeks, he was making very good progress, weight $10 \mathrm{lb} .12 \mathrm{oz}$., length $23^{\prime \prime}$, head circumference $15 \frac{1}{2}$ ". He followed objects with his eyes and head, held his head up well, smiled, and appeared alert generally. Appetite, feeding, and face were normal, and there were no further jerky movements.

He was last seen on December 17, 1951, at 6 months; weight was $14 \mathrm{lb}$. and appearance completely normal. He is a bright, very alert infant, reaching out for objects dangled in front of him, and appears generally more advanced in development and weight than his twin. Blood pressure 80/40.

This patient's non-identical female twin, birth weight $3 \mathrm{lb} .4 \mathrm{oz}$, has been regularly observed but has never shown any abnormality of the eyes.

\section{Case 4, C. B., female, born July 28, 1951 (Figs 4 and 8)}

(1) General Progress before Treatment.-This was the thirteenth child born to a woman aged 40, blood group was $O$ Rhesus (D) positive, only one of whose other children had been premature. She was born after 34 weeks' pregnancy by vertex delivery in an ambulance, no analgesia being given during the labour. On admission to the Premature Unit, the child was cyanosed and weighed $3 \mathrm{lb} .8 \mathrm{oz}$., length $17^{\prime \prime}$, head circumference $12^{\prime \prime}$. She rapidly became oedematous and exhibited marked twitching for the first $48 \mathrm{hrs}$ of 


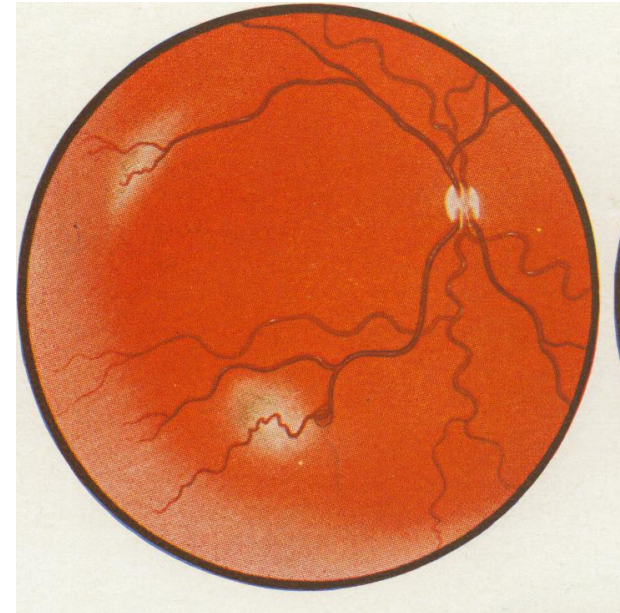

(a)
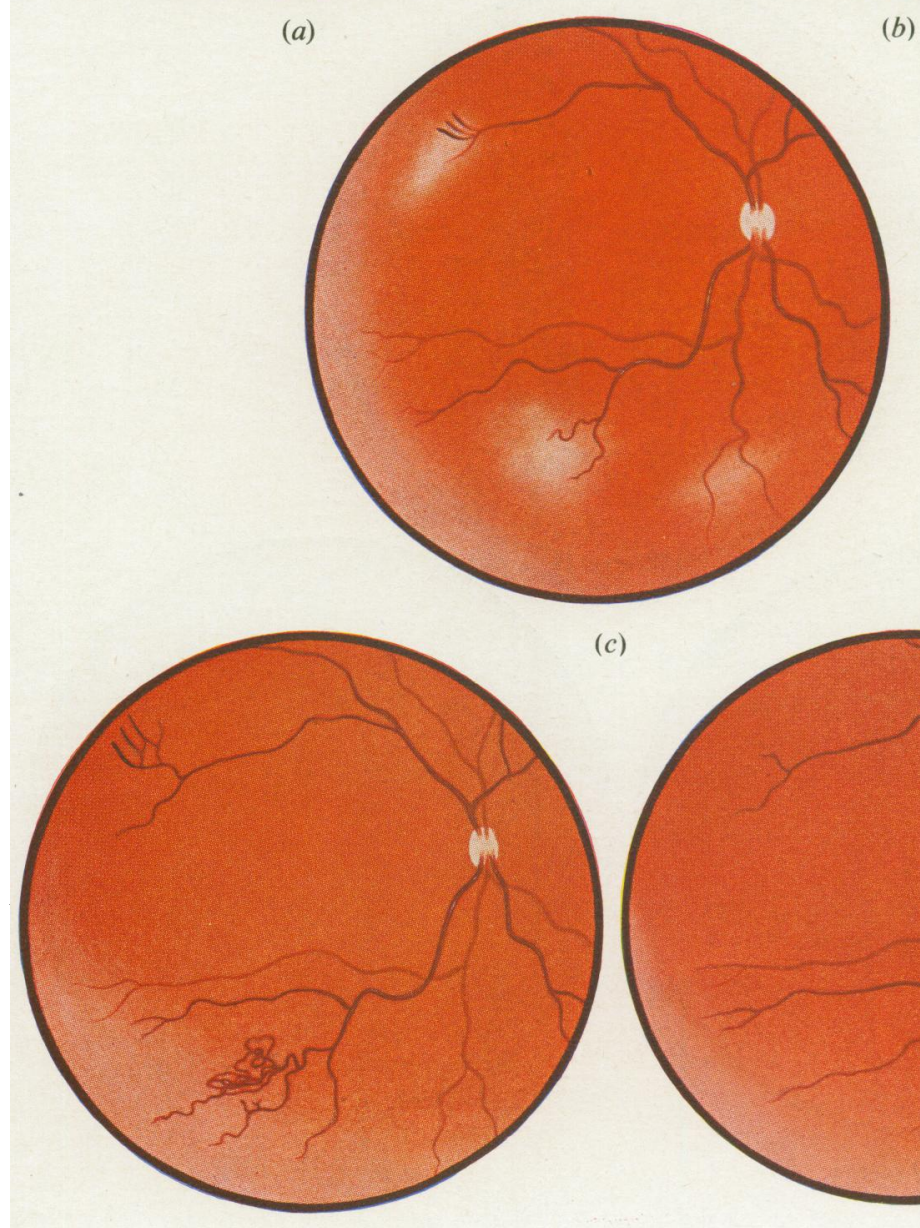

(d)

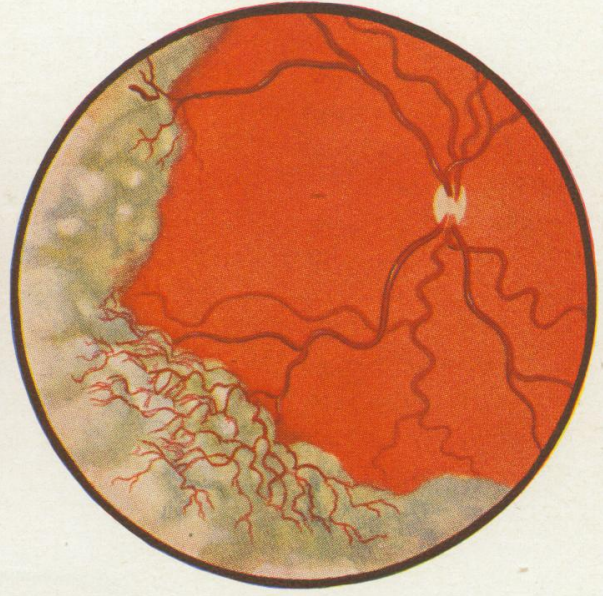

(b)

(c)

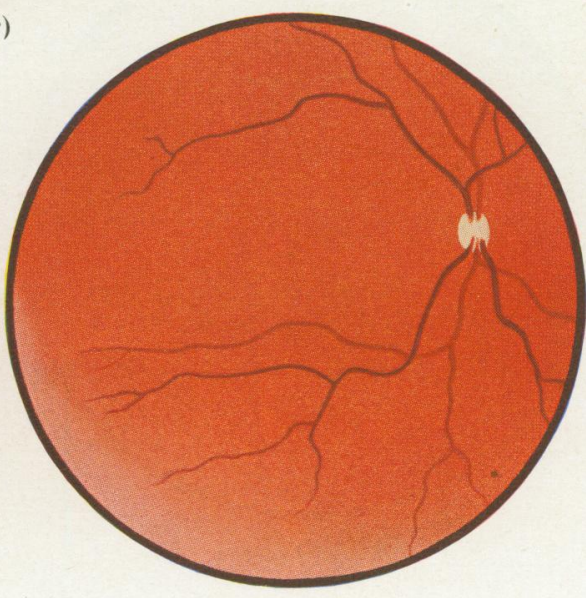

(e)

읃

홈

응

ए

$\vec{\circ}$

产

$\vec{\omega}$

흥

$\omega$

के

$\stackrel{\infty}{\infty}$

잉

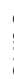

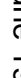

ज़

망

잉

o

ฉั

곡

윽

喜

흥.

옥

ㅇํํ

오

을.

N

옹

స

ర్

은

$\stackrel{0}{?}$

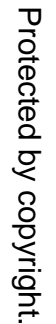




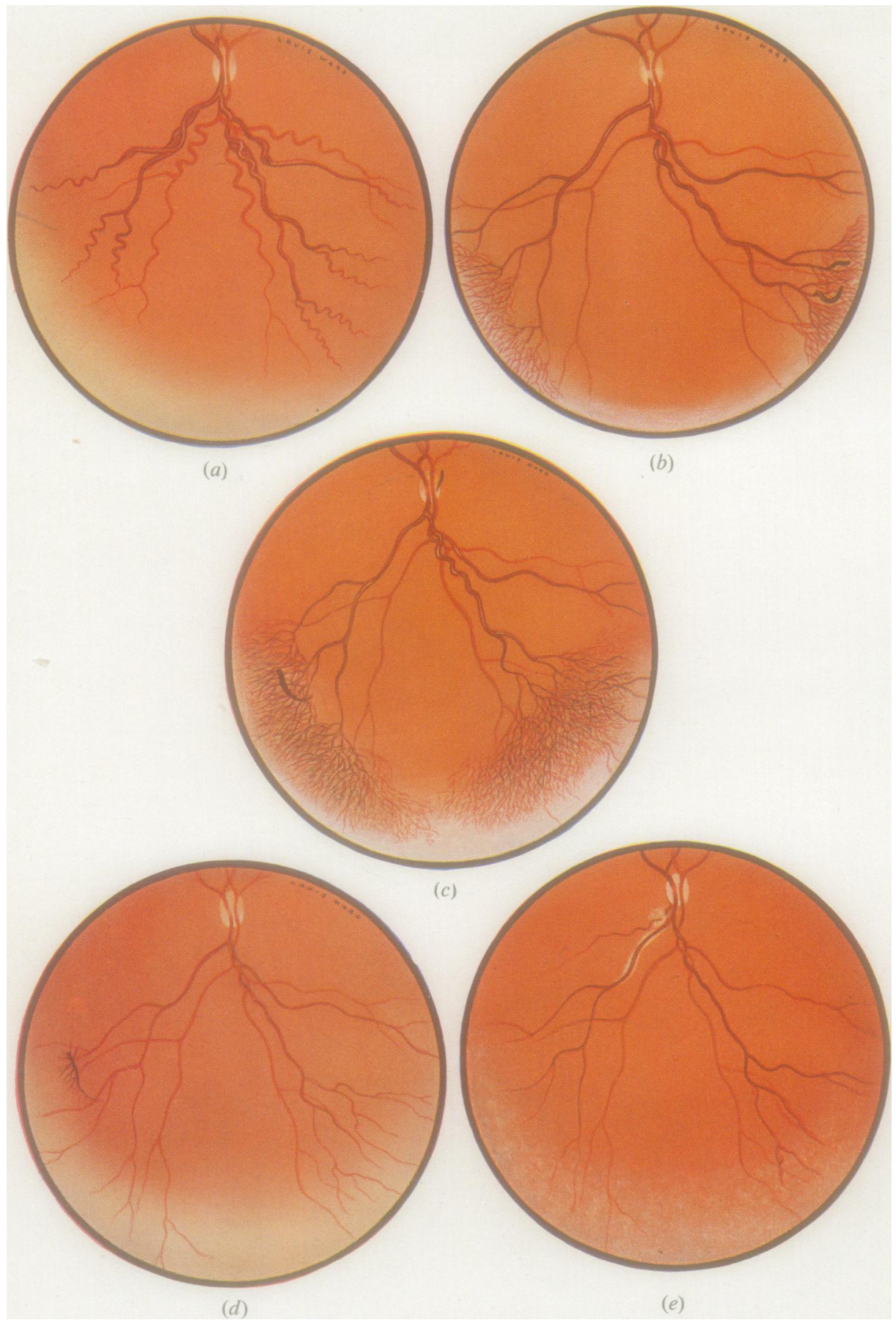

Fig. 4.-Case 4 (C.B.), right eye.

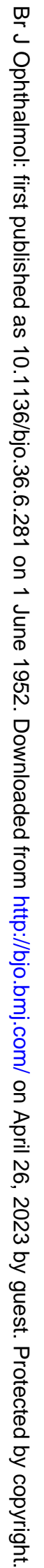




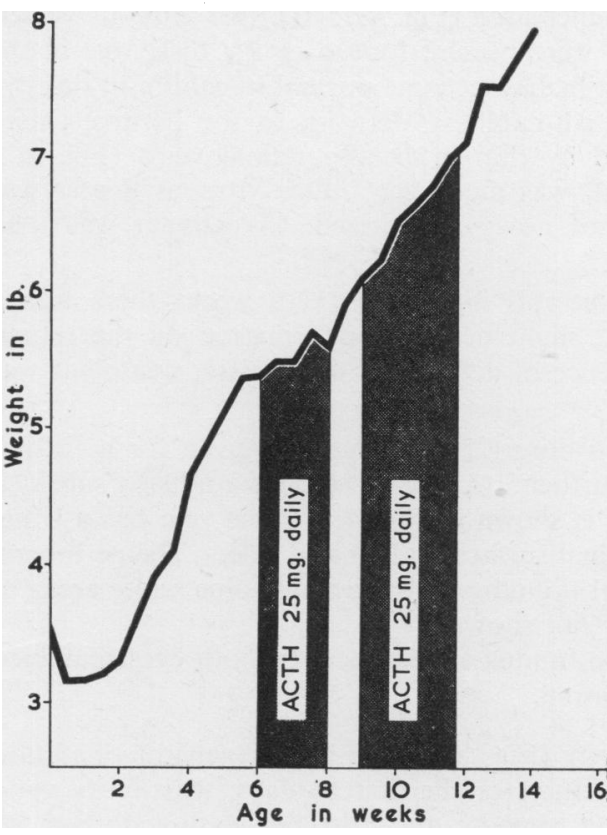

FIG. 7.-Case 3 (R. W.)

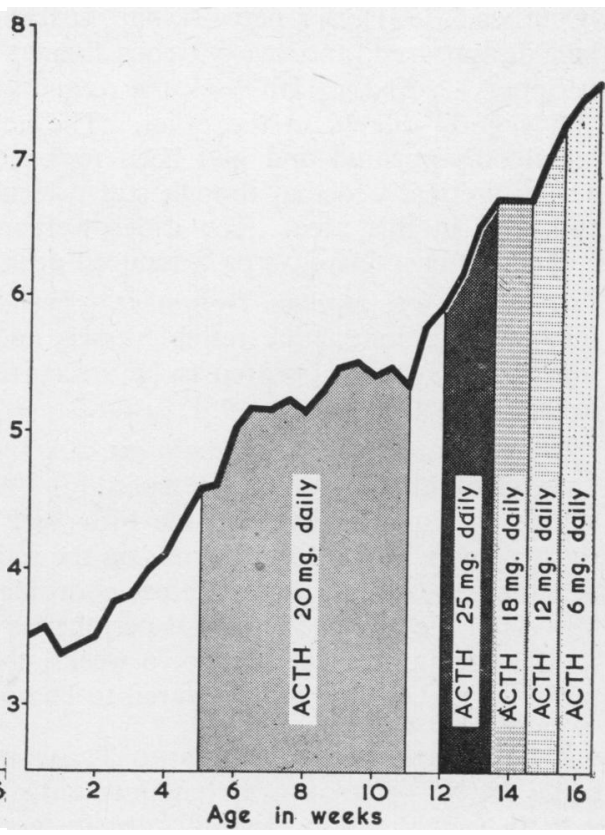

Fig. 8.-Case 4 (C. B.)

life. She was nursed in an oxygen tent with an oxygen flow of 1 to 2 litres per minute for 14 days. On the 4 th day her temperature rose to $102.6^{\circ} \mathrm{F}$. She was then markedly jaundiced and developed multiple small pustules on the trunk (Staph. aureus). Penicillin 30,000 units 4-hourly intramuscularly was given for 5 days. The child was fed by the routine method with breast milk, changing to Frailac on the 14th day, and the usual doses of vitamins were given. There was an initial loss in weight of only $3 \mathrm{oz}$, and subsequent progress was very good, so that on the 16th day the child was $4 \mathrm{oz}$. above birth weight. At 20 days, her weight was $3 \mathrm{lb}$. $13 \frac{1}{2} \mathrm{oz}$., haemoglobin 76 per cent., and general condition completely satisfactory.

(2) Eye Progress during Treatment

(a) Clinical Picture before Treatment.-On August 16, 1951 (20th day), the fundi were normal except for the retinal vessels, which were thinner than normal. On August 30, 1951 (34th day), early retrolental fibroplasia was present (Fig. 4a). The veins were grossly dilated ( 3 times their normal calibre), and the arteries moderately dilated and very tortuous. There was extensive new vessel formation near the disks in the course of the retinal veins. In the periphery there were corkscrew tortuosities of the retinal veins and increased subretinal oedema. There was also early vascularization of the irides.

(b) Effect of Treatment.-ACTH $20 \mathrm{mg}$. daily was started and treatment was continued for 6 weeks (5th-11th week); then, owing to a relapse on stopping the drug, it was continued for a further 5 weeks, the dosage being gradually reduced to zero in the last 3 weeks. By the 7th week the new vessels on the retinal surface near the disk had faded, but there was an increase in the peripheral changes of tortuosity of the veins and subretinal oedema-i.e., the disease appeared to be moving more peripherally. The irides remained vascularized. By the 9th week (September 28, 1951), a network of new capillaries had formed in the periphery all round in both eyes, being most marked in the upper periphery of the right eye (Fig. 4b), where two new vitreous vessels were seen. By the 10th week 
(October 5, 1951), this network had further increased (Fig. 4c); the two vitreous vessels had disappeared, and two vitreous floaters were present (one over the disk, one in the periphery). By the 11th week the retinal veins had become normal in calibre in one eye and slightly dilated in the other. The active capillary network in the periphery had largely disappeared and had been replaced by thin branching retinal veins (Fig. $4 d$ ). The subretinal oedema, though still present, was much less. One vitreous floater was still seen in this area. The irides were not now vascularized. Treatment was then stopped after a few days on a reduced dose.

(c) Effect of stopping Treatment.-Even at this late stage (12th week) there was a further dilatation of the retinal vessels and slight new vessel formation on the retinal surface. As there appeared to be a recurrence of activity of the disease, treatment was restarted on October 19, 1951.

(d) Effect of restarting Treatment.-A full dose $(25 \mathrm{mg}$./day) was given for a further 2 weeks and then gradually decreased for a further 3 weeks. The signs gradually subsided again; the fundus picture at the 14th week is shown in Fig. 4e. One vein has a white sheath, and a new vessel still runs on the retinal surface on its nasal side. The peripheral oedema is now replaced by diffuse choroidal thinning and there are some white areas of fibrosis in the extreme temporal peripheries (not shown).

After being off treatment for 6 weeks, the fundus appearances in both eyes remained fairly normal, and vision appeared to be normal.

(3) General Progress during Treatment (Fig. 8).-The baby's general condition while on ACTH treatment remained satisfactory for the first 14 days, with fairly good gain in weight. Subsequently, despite good appetite and adequate caloric intake, all weight gain ceased for 14 days. At this time the typical round puffy cheeks developed and the child was less active. There was a good weight gain as soon as the treatment was discontinued, but on restarting on October 19 the weight remained stationary once more for 10 days until the dosage was reduced.

On November 1, 1951, towards the end of treatment, the child looked pale and moonfaced and seemed lethargic with less response to stimulation than a normal child of her age. Her blood pressure was then $260 / 60$. During the next 3 weeks her condition greatly improved, she became more alert and active, and started to raise her head up, and by November, 28, 1951, when she was discharged from hospital, her condition was good, blood pressure 170/60. She was alert and active, weighed $8 \mathrm{lb} .10 \mathrm{oz}$., smiled, and responded to the spoken voice. Treatment had been given for a period of altogether 67 days, the total dosage of ACTH being 1,414 mg. When last seen on December 31, 1951, she weighed $10 \mathrm{lb} .15 \mathrm{oz}$., her blood pressure was 100 systolic, and developmental progress appeared normal for her age.

\section{Comment}

(1) ACTH is of no value in established retrolental fibroplasia. This point has already been reported from America (McLean and others, 1951; Scheie and others, 1951) and is confirmed by this series.

(2) ACTH appears to be of value if given early in the course of the disease, and has checked its development in three out of four cases. The rationale of this treatment has been discussed above under " Aetiology". Reese and Blodi (1951) suggest that a deficiency of adreno-cortical hormone in premature infants is due to their being deprived of the normal maternal supply of this hormone. It seems likely, however, that there may be some further factor, as yet unknown, of an infective, toxic, or other nature, which is the immediate cause of the disease. 
In favour of this further factor is the extremely irregular geographical distribution of the disease. One would expect that a purely hormonal deprivation would be evenly distributed throughout the country. There also seems to be a seasonal distribution, at any rate in Bristol. In the last 2 years cases have occurred in spring and summer only, and ten other babies had very dilated veins at the same time of year.

(3) Whatever the cause, the pathological changes consist essentially in:

(a) Dilatation of blood-vessels and formation of new vessels in retina, vitreous, and iris.

(b) Subretinal oedema with retinal detachment.

It is known that in the presence of an inflammatory reaction cortisone has the following effects:

(i) it reduces abnormal capillary permeability in man (Cook and McDonald, 1951);

(ii) it reduces cellular exudative phenomena in aqueous and vitreous both experimentally in animals (Biegel, 1951), and clinically in man (Duke-Elder, 1951);

(iii) it inhibits new vessel formation (Duke-Elder and Ashton, 1951).

Hence ACTH, through its production of cortisone, inhibits the pathological changes in early retrolental fibroplasia, i.e., it decreases the subretinal oedema by decreasing capillary permeability, and it inhibits new vessel formation on retina and in vitreous.

(4) That such changes are reversible in the early stages was clearly shown in Cases 1 and 3, where an acute exacerbation of the disease took place as soon as treatment was stopped, and subsequent re-institution of the treatment controlled the condition. It may be significant that the only case which did not respond to ACTH was the severest and earliest in onset in the series, and was also the only one in which the baby's weight continued to increase normally while on the drug. As already mentioned, there was some doubt as to the activity of the ACTH which this baby received in the early weeks of treatment.

\section{Summary}

(1) Fundus changes in four cases of early retrolental fibroplasia are described.

(2) A general clinical description is given of the pregnancy, birth, and postnatal development of these babies, with details of general management.

(3) The results of treatment with ACTH in eight cases of retrolental fibroplasia are described.

Four established cases were unaltered.

Of four early cases, three were checked and now have normal fundi, and one was unchecked and went on to develop the disease. 
(4) It appears that ACTH can be safely given to premature infants. If it is given early and in sufficient dosage, it may check the progress of the disease and is worth further clinical trial.

(5) The cause of the disease remains obscure. There may be a deficiency of adreno-cortical hormone in these infants as a result of their premature birth, but other factors, toxic or otherwise, may also be involved.

(6) Routine ophthalmoscopy of all premature infants under $4 \mathrm{lb} .6 \mathrm{oz}$. at birth from the 10th day of life till the 2 nd month at intervals of a week or less is advised as the only method of early diagnosis.

We are indebted to Professor A. V. Neale for his interest in this study. Our thanks are due to the Nursing Staffs of the Southmead Premature Baby Unit and the Bristol Eye Hospital, and also to the Department of Obstetrics, Southmead Hospital, for the facilities and records made available. Supplies of ACTH, received through the Medical Research Council, were made available by the United Bristol Hospitals. We are also very grateful to Mr. Louis Ward (in receipt of a grant from the Endowment Fund of the United Bristol Hospitals) for the illustrations.

\section{REFERENCES}

Bifgel, A. C. (1951). Arch. Ophthal., Chicago, 45, 258.

CAMPBell, K. (1951). Med. J. Aust., $2,48$.

ClIFFORD, S. H., and WeLler, K. F. (1948). Pediatrics, 1, 505.

COoK, C., and MACDONALD, R. K. (1951). British Journal of Ophthalmology, 35, 730.

Cross, A. G. (1950). Ophthal. Lit., Lond., 4, 80.

DUKE-ELDER, S. (1951). British Journal of Ophthalmology, 35, 637. and Ashton, N. (1951). Ibid., 35, 695.

Fitzgerald, J. R., Bellows, J. G., Donegan, J. M., Gamble, R. C., Krause, A. C., Mann, W. A., Pearlman, M. D., and Zekman, T. N. (1951). Arch. Ophthal., Chicago, 45, 320.

Gilger, A. P. (1949). Amer. J. Ophthal., 32, 917.

KING, M. J. (1950). Arch. Ophthal., Chicago, 43, 694.

KInSEY, V. E., and CHISHOLM, J. F. (1951). Amer. J. Ophthal., 34, 1259.

and ZACHARIAS, L. (1949). J. Amer. med. Ass., 139, 572.

Krause, A. C. (1946). Arch. Ophthal., Chicago, 36, 387.

Lelong, M., Renard, G., Rossier, A., Lemasson, C., and Michelin, J. (1951). Pr. med., 59, 705.

McLeAN, J. M., GoRdon, D. M., and Koteen, H. (1951). Trans. Amer. Acad. Ophthal. Otolaryng., 55, 565.

MoffatT, P. MCG. (1950). Proc. roy. Soc. Med., 43, 223.

OWENS, W. C., and OWENS, E. U. (1949a). Amer. J. Ophthal., 32, 1.

(1949b). Ibid., 32, 1631.

ReEse, A. B. (1949). Arch. Ophthal., Chicago, 41, 527. and BLODI, F. C. (1950). Amer. J. Ophthal., 33, 23.

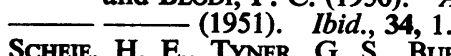

Scheie, H. E., TyNer, G. S., Buesseler, J. A., and Alfano, J. E. (1951). Arch. Ophthal., Chicago, 45, 301 .

TERRY, T. L. (1942a). Amer. J. Ophthal., 25, 203. (1942b). Ibid., 25, 1409.

(1945). J. Amer. med. Ass., 128, 582.

Unsworth, A. C. (1948). Arch. Ophthal., Chicago, 40, 341.

Woods, A. C. (1950). Amer. J. Ophthal., 33, 1325. (1951). Ibid., 34, 945 . 